\title{
A errância no cinema de Walter Salles
}

\author{
El deambular en la película de Walter Salles
}

The wandering in the film by Walter Salles

Cristiane Pimentel Neder

Palavras chave:

Cinema

Criação

Processo Criativo

Walter Salles
Resumo:

Este artigo busca mostrar, a partir da análise da obra cinematográfica de Walter Salles, especialmente com foco no filme Terra Estrangeira, que as escolhas do diretor influenciam no processo criativo, ou são parte dele, e que todo filme é um "filho" com o DNA do diretor, que traz na sua genética, tanto a sua formação acadêmica, artística, quanto as suas subjetividades, seu estilo e sua identidade. 


\section{Resumen:}

Este artículo pretende mostrar, a partir del análisis de la película de Walter Salles, sobre todo centrándose en Terra Estrangeira, que las opciones del director influyen en el proceso creativo, o parte de ella, y que cada película es un "hijo» con la DNA del director y que lleva en su genética, tanto su formación académica, artística, sus subjetividades, su estilo y su identidad.
Palabras clave:

Cine

Creación

Processo creativo

Walter Salles

\section{Keywords:}

Cinema

Creation

Creative Process

Walter Salles

\section{Abstract:}

This article seeks to show, from the analysis of the cinematographic work of Walter Salles, especially with a focus on the film Terra Estrangeira, that the choices of director influence in the creative process, or are part of it, and that the whole film is a "son" with the DNA of the director, that back in your genetics both their academic, artistic and their subjectivities, your style and your identity. 


\section{A errância no cinema de Walter Salles}

\section{Processo Criativo}

Criar é descobrir, elaborar algo diferente ou novo, ou ainda fazer uma releitura do já criado com um novo formato. É descobrir novas possibilidades de conjugar elementos estéticos, teóricos e artísticos. A criação é impulsionada por uma ideia que surge por meio do resgate das coisas armazenadas no consciente e inconsciente da nossa mente. $O$ cinema é uma arte audiovisual que nos exige uma percepção para traduzir em imagens e sons uma ideia, mas não apenas uma ideia, muitas vezes uma metáfora que nos passa inúmeros sentidos, inúmeras aberturas de canais de sensibilidade e reflexões. Um exemplo é o navio encaIhado na praia que surge no filme Terra Estrangeira (1996), de Walter Salles, simbolizando o exílio.

De acordo com o artigo Possibilidades do Processo Criativo, publicado no site da Associação dos Roteiristas, com base nas obras o Espírito Criativo", de Daniel Coleman, e Criatividade, descobrindo e encorajando'", de Solange Muglia Wechsler, as fases do processo criativo são: preparação, incubação, devaneio e iluminação.

Podemos pensar as fases assim: inicialmente temos a preparação, que é quando mergulhamos no problema ou no assunto e pesquisamos tudo o que possa ser relevante; na segunda fase temos a incubação, que é quando ficamos pensando em tudo o que descobrimos e "cozinhamos em fogo brando" aquilo tudo, até crermos que esteja no ponto de maturidade, no ponto de ser revelado, é quando "dormimos" com aquilo que pes- quisamos e deixamos nosso inconsciente buscar possibilidades de semeadura; na terceira fase há o devaneio, que é como sonharmos com os olhos abertos, é quando deixamos o nosso inconsciente nos abrir portas ou mostrar o caminho delas, ou seja, podemos descobrir algo novo ou olhar para algo já conhecido por novos ângulos, por novas perspectivas e relendo o mundo atravessando esferas ainda virgens, é quando tiramos o véu do nosso olhar a cada novo despertar; na quarta fase há a iluminação, que na verdade não é uma iluminação, é apenas o momento em que encontramos o receptor para acender a luz, é o momento em que saímos da escuridão, das ideias cruas, e então damos formato a elas artisticamente, é quando esculpimos o pensamento em obra de arte, é o momento de se divorciar do devaneio para mostrar que aquilo que foi um devaneio tornou-se algo palpável, realizável, que tomou sentido e forma, o momento em que as ideias foram tecidas e que juntas formam uma unidade, um corpo de dimensões ilimitadas ao encontrar-se com o receptor que pode reelaborar sentidos por meio da sua imaginação.

A obra de arte nunca tem um ponto final, porque mesmo depois que o artista a finaliza, o espectador a leva na mente, e daí para frente pode pensar sobre ela de inúmeras maneiras, abrindo um leque de possibilidades de leitura e de percepção. Por isso que uma obra pode inspirar o processo criativo de outra, e o processo criativo de outro alguém pode realizar outra obra também.

O filme Terra Estrangeira nasce de uma imagem fotográfica encontrada na capa de um livro, em que se via um casal à deriva, encalhado em uma praia deserta, como um navio emborcado na areia, assim é o início da gestação do que nasceria anos depois: o filme.Do mesmo autor de Central do Brasil (1998), filme 
que nasce da necessidade de ver o Brasil de dentro para fora, enquanto o filme anterior,Terra Estrangeira, queria vê-lo de fora para dentro.

Assim como os autores encontram inspiração para criar coisas originais, ou semi originais, inspiradas em algo já existente, ou que dialoga com o que já foi criado, depois que uma obra é criada, outras pessoas podem absorver seus referenciais artísticos e criar novas obras, influenciadas por elas ou por um conjunto delas.

No prefácio do livro Terra Estrangeira (Salles \& Thomas, 1997), um livro de fotogramas baseado no filme, José Avellar escreve: "Cinema não se reduz à imagem que passa na tela: é também o que o espectador inventa no imaginário, como resultado da tensão entre o que viu e o que persiste na memória". Desse modo, percebemos que o que o espectador leva embora com ele pode ajudá-lo a criar outra obra em cima da original.

\section{O Processo Criativo no Cinema de Walter Salles}

Pensar e fazer cinema é dar sentidos conotativos àquilo que visualizamos e também ao som para nos levar a um lugar ou a um estado emocional. Somos transportados ao lugar da cena ou para os acontecimentos ao redor dos personagens e das suas atmosferas psicológicas e emotivas por meio do filme.

Quando nós escutamos o apito de um navio ao longe, em Terra Estrangeira, acabamos nos envolvendo na situação de não podermos partir, mesmo sendo chamados, mesmo a vontade sendo a de fugir,estamos com o corpo encalhado em algum lugar, assim como o navio. Salles não escreve frases longas nos seus roteiros, ele deixa que as imagens e os sons falem por si só.
Em Central do Brasil, o banheiro de estrada masculino, sinalizado com "Omem", assim mesmo, faltando o "H", reflete o Brasil deficiente na educação. Uma palavra em uma letra pode ter uma extensão de sentidos imensa, e segundos da cena podem representar um labirinto para várias reflexões. Salles deixa lacunas abertas para que o espectador possa refletir. Ele faz um cinema de estrada, em que pegamos a estrada com ele e não chegamos nunca à casa, ou quando chegamos, como em Central do Brasil, a casa já não tem mais a figura paterna, a casa não é aquela que sonhávamos, não é mais onde os nossos sonhos moram. Terra Estrangeira é um filme que termina sem terminar, que segue uma estrada sem fim e a imagem vai-se embora, mas a estrada continua lá.

Há uma atração pela estrada em toda a obra de Walter Salles e, embora ele não queira relacionar seu processo criativo à sua biografia, mas ao seu processo criativo em si, uma coisa de sua biografia é importante que seja lembrada, que o pai do cineasta foi embaixador e que estradas que não terminam fazem parte da sua vida interminavelmente. Um embaixador é uma figura muito ausente em vários sentidos, tanto do país quanto da família, e a busca pelo pai e pela pátria são marcas do cinema de Walter Salles. Além disto, Salles passa e passou boa parte da sua vida fora do Brasil.

Sobre o filme Na Estrada (2012), adaptação do livro On the Road (1957), de Jack Kerouac, o cineasta deu uma entrevista ao jornal Zero Hora, em 7 de julho 2012, e falou sobre o processo de filmagem. Ao jornalista na matéria, Salles falou da sua fascinação sobre filmes de estrada. Salles cita Wim Wenders: "O cineasta Wim Wenders diz que, à medida que você se distancia do seu ponto de origem, ganha perspectiva e pode entender melhor de onde vem e, por extensão, 
quem é. Os relatos de estrada são, por definição, relatos de transformação de personagens que não estão confortáveis em seus lugares. A errância possibilita que isso aconteça". Salles, na maioria dos seus filmes, faz com que seus personagens se distanciem do seu ponto de origem para entenderem quem são. Ele faz os seus personagens se perderem, não para depois se "encontrarem", mas para talvez se reconhecerem.

O jornalista fala ao cineasta que a busca pelo pai é uma constância em seus filmes, e acerca disso fala do personagem Dean de Na Estrada: "Na minha filmografia, a busca pelo pai também é uma busca pelo país. Você vê isso em Terra Estrangeira, Central do Brasil e mesmo em Linha de Passe (2008). Dean também busca o pai, mas ele mesmo não está preparado para ser um pai. Esse tema está muito mais no manuscrito do que no livro publicado."

A ausência do pai e a ausência da pátria estão sempre presentes nas obras de Salles, ele gira em volta deste mesmo ponto em várias de suas criações. Há assuntos que incomodam os diretores e eles têm necessidade de mexer na ferida. Percebe-se que o processo de criação passa por uma necessidade de urgência, de o artista colocar para fora tudo aquilo que ele não consegue se desfazer, a não ser transformando em arte.

A linguagem de Salles, na maioria de suas obras, é uma ficção, mas com vertente documental. Terra Estrangeira é uma ficção, mas partindo do fato real do confisco do dinheiro da poupança realizada no Governo Collor no Brasil. Salles busca fatos da realidade para começar uma estória de ficção, por isso também Salles é considerado um dos cineastas do movimento chamado no Brasil de Novo Cinema Novo, assim denominado por ser o cinema da retomada de produções, um pe- ríodo de novo fôlego após a fase nebulosa do governo de Fernando Collor de Mello, que prejudicou o cinema nacional. O Novo Cinema Novo leva este nome inspirado no Cinema Novo e, assim como ele, grande parte de suas obras está preocupada com a verossimilhança, com a verdade e a realidade. Senão partindo de fatos da realidade, como em Terra Estrangeira, ao menos não romanceando os fatos, devorando-os com casca e tudo.

Salles, nos filmes A Grande Arte (1991), Terra Estrangeira (1995), Central do Brasil (1998), O Primeiro Dia (1998) e Abril Despedaçado (2001), mostra as coisas como elas são, mas sempre de um modo poético, sem agressão. Há cenas de violência, mas a violência de Salles não é uma violência explícita, é uma violência que poderíamos talvez denominar "refinada", se é que violência possa ser refinada, mas a chamamos desse modo porque o diretor cria cenas em que a dor não atinge o espectador, não no sentido de não emocionar ou sensibilizar, mas no sentido de ele não sentir aflição com aquilo que é mostrado. É uma violência com amortecedor. Por exemplo, no filme O Primeiro Dia, há uma cena de um tiro, momento em que escurece a tela e só ouvimos o barulho do tiro e nada mais. Não se vê o morto, não se vê a ferida. É do estilo de Salles ser intenso, mas sem ser visceral. Ele consegue nos mostrar o sofrimento e a dor, mas sem causar mal-estar. É uma dor e um sofrimento na vitrina, participamos estando do lado de fora.

Percebe-se que há aspectos no cinema de Walter Salles que muito se aproximam do cinema feito por Wim Wenders. De alguma maneira, Wenders o influencia e,em algumas entrevistas, Salles sempre recorre a reflexões do cineasta alemão. Um dos focos do cinema dos dois é a busca pela identidade. Wim Wenders, em seu filme O Céu de Lisboa (título no Brasil), mundialmente conhecido como 
Lisbon Story (1994), busca a identidade de uma Europa unificada pela Comunidade, mas separada por suas subjetividades e processo histórico de cada região que compõe a unidade. A obstinação de ambos os cineastas pela estrada é recorrente em suas obras, e nós viajamos junto por meio dessas obras. Eles nos levam a refletirmos sobre a identidade coletiva e individual e nos provocam a sermos de um lugar, sem estarmos, e estarmos em um lugar, sem sermos.

O Cinema Novo também é referência para irmos atrás desta identidade que Walter Salles tem interesse, porque o movimento pensou o Brasil penetrando nas suas entranhas, na sua gente, na sua origem, questionando os seus problemas políticos e sociais. Um cinema que gritou para o brasileiro escutar a sua própria voz. O cinema de Salles é a reverberação desta voz, que ele faz sem consciência de fazer, mas que, a partir do momento em que ele filma, ele já começa a fazer, pois, buscando as nossas identidades, ele cava um buraco que volta ao Cinema Novo, mas que é diferente, porque já faz parte de um mundo globalizado, onde as nossas feridas são também compartilhadas com outras vidas de qualquer lugar. $\mathrm{A}$ busca do pai e da pátria são buscas cada vez mais contemporâneas nesse de mundo de refugiados e de nacionalistas. $\mathrm{O}$ cinema de Salles fala hoje de um problema nacional, mas também de um problema mundial. Ele, em seu processo de criação, parte do todo para os fragmentos e dos fragmentos para o todo.

Diretor também de Diários de Motocicleta (2004), filme em que ele relata as viagens do líder revolucionário cubano Che Guevara e do seu amigo Alberto Granado, novamente o diretor vai "cair" na estrada. Ele gosta de estórias que correm no asfalto, no chão batido de terra, nos Minhocões da vida (viaduto ao lado do qual o personagem Paco mora, no filme Terra
Estrangeira, local onde passam carros noite e dia sem parar, onde o barulho de ir e vir não nos deixa dormir). A estrada, o caminho, a pista são elementos de gestação nas obras do cineasta. Seus filmes têm movimento a quase todo momento. Seus pensamentos seguem uma estrada para poder realizar um filme.

Salles sempre quer nos levar para algum lugar junto com ele. Os leitores podem pensar que todo cineasta quer nos levar a algum lugar, mas não tratamos aqui do lugar reflexivo que todos os artistas nos levam de uma maneira ou de outra, mas tratamos do lugar para o qual é necessário deslocamo-nos para chegarmos. Em Terra Estrangeira, o personagem Paco precisa chegar a San Sebastian, na Espanha, para ver pelos olhos dele os sonhos da mãe, e assim completar o desejo que ela não concretizou antes de morrer, e nós acompanhamos Paco nessa trajetória durante todo o filme. Sofremos as desilusões dele, herdamos o sonho da sua mãe e partimos para um exílio escolhido. Salles nos faz sentir os medos do viajante, a solidão que o acompanha, nos faz sermos viajantes em uma experiência completa: de ser porque se desloca e de ser porque está em busca de si próprio.

$\mathrm{Na}$ sua participação em um dos momentos que integram Paris, Te Amo (2006), um filme formado por um mosaico de filmes curtos, de autores de diversos países que escrevem sobre a capital da França, ele conta a estória de uma babá latina na Europa, que deixa a sua filha para cuidar da filha dos outros. O filme curto que ele realiza para integrar um dos pedaços da obra geral não tratada beleza da cidade, do que é ser parisiense ou de como Paris é uma cidade encantadora, ele mostra uma pessoa que, embora esteja em Paris, não participa de Paris, porque ela está sempre na casa dos outros, seja a casa física ou a casa pátria. 
Uma das preocupações centrais de Salles nas suas obras é mostrar como é sentir-se um estrangeiro, não apenas o estrangeiro que sai do seu país para outro, mas do estrangeiro em qualquer circunstância. Estrangeiro porque é excluído dentro do seu próprio país, estrangeiro porque vive à margem de tudo ou num lugar que não é lugar nenhum, mas, apenas, ponto de passagem para vários lugares, como Paco e seu apartamento do lado do Minhocão. Estrangeiro porque não se percebe daquele lugar ou porque não consegue achar o seu espaço naquele lugar. Estrangeiro porque se estranha ou é estranhado de alguma forma, seja física, afetiva, social ou por qualquer circunstância em que não consegue se encaixar ou se adaptar em relação a algo ou alguma coisa. O processo criativo de Salles passa por essa angústia de buscar a identidade não só de pátria, mas da "alma", daquilo que mora no coração ou de onde o coração mora e não apenas onde habitamos.

Seu processo de criação passa pela busca constante da identidade do espaço territorial, social e afetivo do útero enquanto espaço de abrigo e não apenas de gestação. Em Paris, Eu Te Amo, a personagem do seu curta, chamada Louin $D u$, levanta bem cedo, com a cidade ainda escura, e leva seu bebê para uma creche. Ela deixa o filho ou filha (não fica explícito se é um menino ou uma menina) na creche, pega o trem lotado e vai trabalhar, olhando a cidade através da janela do vagão e, pelo seu olhar vago, percebemos que ela olha a cidade, mas está longe, pensativa. No vagão lotado, ela se mexe para deixar os passageiros saírem nas estações e olha no relógio no pulso, preocupada com seu horário de trabalho. Ela sai do vagão com pressa de chegar logo, no ritmo acelerado da cidade grande, que faz termos uma vida automática, sem ver por onde passamos e as pessoas que cruzamos. Na sequência, o curta mostra a personagem pegando mais de um trem, fazendo baldeação, como se ela morasse na periferia de Paris e trabalhasse em um bairro mais central. Ela chega a um prédio, aperta o interfone com ansiedade e olha no relógio novamente, entra correndo.

A personagem do seu curta em $\mathrm{Pa}$ ris, Eu Te Amo olha Paris pela janela e à sua frente há um prédio alto que esconde a paisagem. $\mathrm{O}$ cineasta, em seu processo de criação, está sempre nos mostrando o mundo, não pela visão de cartões postais, mas por outros caminhos periféricos e fazendo-nos enxergar por outros ângulos o mundo que grande parte das pessoas excluídas vê, um mundo visto pela janela, pequeno, estreito sem que elas possam participar dele.

Em seu filme O Primeiro Dia, a visão de mundo de quase todos os personagens é pela janela: da janela da cadeia, de onde se vê o metrô passar ao lado; da casa, que dá vista para a favela, cena mostrada ao final do filme, após um final de ano, uma representação de que nada mudou, embora um novo ano tenha começado.

Sempre existe um trem, um metrô, um ônibus, uma carta, um avião, um navio ou uma moto em destaque em seus roteiros, passando pela vida dos personagens, transportando-os para os sonhos ou transportando os seus sonhos por meio deles.Há sempre uma circulação, um movimento de gente indo e voltando em seus filmes; há também alguém observando ou partindo, com o olhar, o pensamento, ou ainda fisicamente. $\mathrm{O}$ diretor mostra como é viver em uma cidade grande e não perceber nada, a personagem até dorme de cansaço no vagão, sua única preocupação é sobreviver, é ir e voltar, da casa para o trabalho e do trabalho para casa. $\mathrm{Na}$ maioria dos filmes de Salles, os personagens estão sempre em trânsito, em movimento, e mora dentro deles uma angústia de chegar a algum lugar sempre, mesmo 
que seja um lugar utópico. É recorrente também o abandono de algo do personagem no meio do caminho, nem que seja o abandono da sua identidade.

Uma característica dos seus roteiros é a colocar as pessoas sempre procurando uma fuga: psicológica, social, econômica ou de si mesmo. Seu curta no filme Paris, Eu Te Amo mostra que a personagem não é de lá, mesmo não sendo caracterizada a sua nacionalidade, sabemos que ela é estrangeira, pois o patrão fala com ela e ela faz cara de quem entende pouco, concordando com tudo.

O que é importante observar no processo de criação de Salles é que os personagens, na maioria das vezes, são estrangeiros ou retirantes e, também na maioria das vezes, estão em fuga. Estão fugindo de uma vingança, de um acerto de contas, da morte, do desequilíbrio físico e mental, da miséria, do medo, do abandono dos pais ou da pátria.Estão em fuga quase sempre, não conseguem parar de fugir, seja correndo na rua, no trem, no ônibus, na moto, no carro ou via qualquer meio de locomoção. Suas estórias geralmente não são paradas, não são monólogos, têm poucas cenas internas. Ele é um diretor do ambiente externo, do exterior das pessoas e do exterior dos lugares. Ele acompanha com a câmera a fuga dos seus personagens, ele os persegue com a câmera e leva-nos junto. Em Terra Estrangeira, as pessoas pisam em diamantes em uma estação de metrô e nem se dão conta disso.

Além da fuga, Salles gosta de salientar, de modos muito sutis, os incômodos culturais que um estrangeiro sente, como em Terra Estrangeira,quando a personagem de Fernanda Torres fala que quanto mais ela tem consciência do seu sotaque, mais ela se sente estrangeira. Os problemas dos imigrantes e emigrantes são tão repetitivos na obra de Salles porque ele é um diretor que trava um diá- logo com diretores e obras internacionais e nacionais, ele consegue pensar o global regionalmente e pensar o regional globalmente. Ele consegue sentir as dores de quem se desloca, porque ele se coloca no lugar deles, ele os observa antes de dirigir e escrever. Considero o Salles, não apenas um diretor brasileiro, mas um diretor do mundo, porque ele é um dos poucos diretores que tem amizades com diretores de várias nacionalidades, que faz um cinema híbrido nacional e estrangeiro ao mesmo tempo, como são suas obras e seus personagens. Ele pensa o cinema além das nossas fronteiras.

Algumas imagens são viciantes no processo criativo de Salles.Em grande parte dos filmes dele, por exemplo, a janela do ônibus e do caminhão, como em Central do Brasil, são objetos usados para que o olhar subjetivo dos personagens se projete para o lado de fora, mas estando, na verdade, o olhar subjetivo projetado para dentro, para muito longe dali, não apenas na distância em relação ao ponto de partida, mas na distância do pensamento. Propositalmente os personagens pensam, sonham, refletem e saem do corpo para visitar a alma. Em todo filme dele a janela é o lugar de pensar na vida, no mundo, olhar por onde se passa, estando presencialmente em um local, mas espiritualmente em outro.

Nos filmes de Salles os personagens viajam sem deixar suas origens, e vemos muito bem isso em suas estórias. A mãe de Paco, em Terra Estrangeira, vive no Brasil, mas nunca abandonou San Sebastian. As janelas dos diversos meios de transporte e os vidros e retrovisores dos carros e motos são objetos que ele usa para deslocar o pensamento do personagem de lugar. Quanto mais o personagem vai chegando próximo ao seu destino de viagem, ou lá se fixa, na verdade mais próximo ele volta ao seu destino de origem nas obras de Salles. A viagem, na contra- 
mão do que se busca e do que se encontra, é uma constância em sua obra, além dos contrastes, que fazem parte dos seus filmes. Contrastes do tipo: quanto mais abandonamos o nosso país, mais ele está presente dentro de nós, mais o ressuscitamos quanto mais o perdemos de vista.

Filmar em preto e branco Terra Estrangeira foi uma decisão que tornou a obra mais poética ainda, com a intencionalidade de mostrar que o filme trataria de tempos sombrios no Brasil, de um tempo sem cor, mas ao mesmo tempo do exílio, que é sempre período de tristeza, seja esse exílio forçado ou não. Terra Estrangeira tem a cor do exílio, que é a ausência de pátria, a ausência de pai e de mãe em vários sentidos, a palavra paternidade passa a ser representada, inclusive, como orfandade de país e de futuro.

A ideia do preto e branco nasce inspirada em observações da fotografia de Robert Frank (fotografo suíço que fez carreira nos EUA na famosa Beat Generation). Salles, ao pesquisar sobre a intencionalidade do preto e branco nas obras de Frank, descobriu que, para o fotógrafo, essas eram as cores da esperança e desesperança. A escolha do preto e branco no filme simboliza também o vazio da ausência, da saudade, da perda e do abandono da vida antiga.

Mesmo quando seus filmes não são em preto e branco, eles têm um colorido diferente para simbolizar estados e situações diferenciadas, como por exemplo, na primeira parte do filme Central do Brasil, em que o Centro da cidade do Rio de Janeiro tem uma cor que transmite a sensação de claustrofobia, que é recorrente em outras obras dele em cidades grandes. A sensação de claustrofobia é reforçada no vagão do trem e do corredor do prédio da personagem Dora. Não há horizonte, é o concreto urbano cinza, sem o azul do céu. Nessas cenas, a lente é mais fechada, como o horizonte, e a visão de mundo dos personagens é como se eles estivessem espremidos pelo progresso e pela falta de perspectiva de mudança e de saída para outra vida. A partir do momento em que os personagens entram na estrada, as lentes vão se abrindo e as cores ganham novos tons cromáticos, fugindo do cinza do concreto do início do filme.

A cor cinza predominante no início, como em Central do Brasil, é justificável. É como se a estação de trem do Rio fosse monocromática e que, embora estivesse sempre em movimento, não mudava de cor a realidade dura das pessoas, sua cor estática é sinal de que os vagões de trem saem do lugar, mas não transformam a vida das pessoas transportadas nele, que aquela rotina estressante e exaustiva não tem espaço para tons mais coloridos e vivos, mais vibrantes e menos asfixiantes. Cor é sinal também de uma atmosfera alegre, algo que não há na Central do Brasil, e o diretor captou isto no ar. Walter Salles tem uma leitura das atmosferas dos lugares em seus filmes e ele demonstra isso na troca das lentes na hora de filmar e na mudança de focos e tons.

Quando os personagens dele em Central do Brasil entram na estrada, não apenas eles acabam espairecendo e tomando um ar novo em suas vidas e rumos, mas também é como se a imagem respirasse, percebesse as cores ao redor de si. A travessia da fronteira entre a cidade grande do Rio de Janeiro rumo ao interior do Nordeste é sentida no olhar, pelo tom ocre da terra seca. O filme também fica com cores mais vivas e intensas quando a personagem Dora deixa de ser egoísta e começa a se preocupar com outro ser. É como se a partir desse momento sua vida ganhasse um novo colorido, como se ela tivesse se divorciado de uma nuvem escura em cima de si, como se sua visão de mundo tivesse se aberto a partir do instante que não pensa apenas em si, mas se 
preocupa com o outro. Propositalmente, o diretor nos mostra que a visão de Dora mudou a partir do momento em que ela se doa e pensa no outro. É um mundo novo que se abre à frente dela e nós, espectadores no cinema, também participamos dessa nova vida.

A personagem Dora também tem poder sobre a vida dos outros, poder que se dá quando ela resolve mandar ou não as cartas que ela escreve para os analfabetos.Ao enviar as cartas, ela acaba transformando a vida de alguém efetivamente e, por isso, seu mundo muda de cor. O processo de criação do Salles tem quase sempre escolhas de paisagens fotográficas e sonoras contrastantes para cada mudança de rumo, de realidade, de comportamento e de visão de mundo dos personagens.

Em Central do Brasil, na casa de Jessé, no meio do nada, o silêncio é ensurdecedor, cortado apenas pelo ruído do vento. Em quase todas as suas obras os sons e as cores se abrem ou se fecham, conforme a intenção do diretor no roteiro. As cores podem se abrir quando o personagem se aproxima da sua identidade, e podem se fechar quando ele perde sua capacidade de olhar além de si, e por aí em diante. Salles aproxima e afasta cores e sons conforme os personagens ficam mais próximos dos seus destinos, dos seus objetivos, ou sofrem uma transformação.

Salles também trabalha com antagonismos em suas obras, sempre com pares complementares e diferentes, do tipo: nacional - estrangeiro; Brasil - exterior; cidade grande - sertão; centro - periferia; favela - miolo da cidade. É como se ele sempre falasse de um apartheid entre mundos opostos, entre realidades opostas, entre culturas opostas. Seu processo de criação passa pela observação dos contrastes entre uma coisa e outra.
Alguns cineastas influenciaram no seu processo criativo diretamente, como Antonioni, em Abril Despedaçado, filme em que o sertão árido é espelhado na personalidade dos personagens. A seca é um estado emocional e não apenas climático. A paisagem fala com o espectador enquanto o filme é exibido. A paisagem torna-se um personagem.

\section{Considerações finais}

Falar de Walter Salles e do seu processo criativo é falar da busca da identidade e da perca. É falar de nacionalidade não como um lugar de nascimento, mas de sentimento. É falar de seu processo de criação em conjunto com a observação da alteridade entre coisas, realidades e pessoas distantes, e ao mesmo tempo próximas, distantes pelos contrastes, próximas pelas afinidades de sonhos ou de buscas. Seu processo de criação é uma permanente busca da compreensão do outro estranho, estrangeiro, passageiro, nômade. Do outro que não tem lugar fixo a não ser na história. Seu processo de criação passa sempre pela estrada da vida e da ficção.

\section{Bibliografia}

ASSOCIAÇÃO DOS ROTEIRISTAS. Possibilidades do Processo Criativo. 27/02/2012. Disponível em: http://www.artv.art.br/index.php/estudos/118-possibilidades-do-processo-criativo-. Acesso em: 8 ago. 2016.

CHIODETTO, Eder. Lançamento da Relume Dumará reúne fotogramas do filme 'Terra Estrangeira', o livro, serve de memória da retina. Folha de São Paulo [online], Folha de São Paulo llustrada, 27/09/1997. Disponível em: http://www1.folha. uol.com.br/fsp/ilustrad/fq270916.htm. Acesso em: 8 ago. 2016. 
LERINA, Roger. (2012). O diretor Walter Salles fala sobre o processo de filmagem de "Na Estrada". Jornal Zero Hora, 07/07/2012. Disponível em: http://zh.clicrbs.com.br/rs/entretenimento/ noticia/2012/07/o-diretor-walter-salles-fala-sobre-o-processo-de-filmagem-de-na-estrada-3814144.html. Acesso em: 8 ago. 2016.

SALLES, Walter; THOMAS, Daniela. Desejo de cinema. Terra Estrangeira. Rio de Janeiro: Relume Dumará, 1997.

\section{Filmografia}

A grande arte (1991), de Walter Moreira Salles Júnior.

Abril despedaçado (2001), de Walter Moreira Salles Júnior.

Central do Brasil. (1998), de Walter Moreira Salles Júnior.

Diários de motocicleta (2004), de Walter Moreira Salles Júnior.

Linha de Passe (2008), de Walter Moreira Salles Júnior e Daniela Thomas.

Lisbon Story (O céu de Lisboa) (1994), de Win Wenders.

O primeiro dia (1998), de Walter Moreira Salles Júnior e Daniela Thomas.

Paris, Je T'Aime (Paris, eu te amo) (2006), de Alexander Payne, Alfonso Cuarón, Bruno Podalydès, Christopher Doyle, Daniela Thomas, Emmanuel Benbihy, Ethan Coen, Gérard Depardieu, Gurinder Chadha, Gus Van Sant, Isabel Coixet, Joel Coen, Nobuhiro Suwa, Oliver Schmitz, Olivier Assayas, Richard La Gravenese, Sylvain Chomet, Tom Tykwer, Vincenzo Natali, Walter Salles, Wes Craven.

Terra estrangeira (1995), de Walter Moreira Salles Júnior e Daniela Thomas.
I Brasil. Cristiane Pimentel Neder. Mestrado e Doutorado pela Escola de Comunicações e Artes da USP - Universidade de São Paulo; Pós-Doutorado pela Universidade Federal de Santa Catarina - UFSC. Professora no curso de Comunicação Social na UEMG - Universidade do Estado de Minas Gerais. Cidade: Frutal - Minas Gerais. Contato: nederescritora@hotmail.com.

II GOLEMAN, Daniel. Espírito criativo. 3. ed. São Paulo: Cultrix, 1999.

III WECHSLER, Solange Muglia. Criatividade: descobrindo e encorajando. 3. ed. Campinas, SP: Livropleno, 2002. 